\title{
Sosyo
}

Ekonomi

\section{The Syrian Energy Policies of the "Four Seas" and Their Geopolitical Repercussions}

John KARKAZIS

ikarkazis@aegean.gr
Ioannis VIDAKIS

johnvidos2000@yahoo.gr
Georgios BALTOS

abc@abc.gr

\section{Suriye’nin “Dört Deniz” Enerji Politikaları ve Bu Politikaların Jeopolitik Yansımaları}

\begin{abstract}
The article gives, first, a brief historical review of the development of the oil and natural gas sectors of Damascus. Next, the article focuses on oil pipeline networks in Syria, the geopolitical controversy introduced by them and the various investment projects in the energy sector pushed forward by the Syrian government. Finally, the article analyses president Assad's grand energy policies of the "Four Seas" aiming to transform Syria to an energy networks hub in the Region and comments on the arising geopolitical repercussions.
\end{abstract}

Keywords

JEL Classification Codes
: Energy, Energy Resources, Energy Policy, Energy

Security, Syrian Energy Policy, Middle East.

A12, F50, N75, Q48.

\section{Özet}

Çalışmada öncelikle Şam'daki doğal gaz ve petrol sektörlerinin gelişimi ele alınmaktadır. Daha sonra Suriye'deki boru hattı şebekeleri ve bunlar üzerinde yapılan jeopolitik tartışmalar ile Suriye devleti tarafindan enerji sektöründe yapılmak istenen çeşitli yatırım projeleri üzerinde durulacaktır. Çalışmanın sonuç kısmında ise Suriye Devlet Başkanı Esad "Dört Deniz" enerji politikaları ile gerçekleştirmeye çalıştı̆̆ ve Suriye'yi bir enerji dağıtım üssü haline getirmeyi amaçlayan politikaların jeopolitik yansımaları üzerinde durulacaktır. 


\section{Acknowledgement}

This paper presented in International Congress on "Energy Security in Eastern Mediterranean", Mersin - Turkey, 14-18 December 2013.

\section{Beyan}

Bu çalışma, daha önce 14-18 Aralık 2013 tarihinde Mersin'de düzenlenen Uluslararası Doğu Akdeniz'de Enerji Güvenliği Kongresinde bildiri olarak sunulmuştur. 


\section{Introduction}

According to the «U.S. Energy Information Administration» (EIA, 2013), Syria is the only oil producing country in the Eastern Mediterranean (an area including also Jordan, Lebanon, Israel, Cyprus, and the Palestinian Territories). Syria produces relatively low quantities of hydrocarbons from land deposits. Oil is exported to Europe and natural gas is used to upgrade oil pumping operations and also for domestic production of electric energy.

On the other hand Syria's location is strategic with respect to the security of energy flows and also as a hub in the energy transfer networks. Before the Syrian crisis the regional cooperation on energy, with the initiation of a number of major projects involving Syria, was proceeding at a fast pace. These plans regarded mainly the extension of existing energy supply networks to connect Syria with neighboring countries (Turkey, Iran, Iraq and also Azerbaijan) creating also an "added value" for the existing energy axes connecting Egypt and Lebanon.

Furthermore, the recent discovery of large quantities of hydrocarbon deposits in a relatively unexplored part of eastern Mediterranean Sea (between Turkey, Cyprus, Israel, Syria and Lebanon) is expected to further enhance the geo-economic importance of Syria as an energy networks hub.

In this paper, after a brief review of the Syrian energy sector, we present an appropriate and justified interpretation of the energy policy of this Arab country, especially through the "model of geopolitics and geo-economics of energy" "geo-energy approach", Karkazis, Vidakis, Baltos, 2010).

At this point one should always bare in mind that an intense domination struggle from oil and for oil erupted among the big oil companies drawing, in many cases, the intervention of governments and other state organizations. Oil and gas can be (relatively) easily transformed into huge financial resources and economic power through which a wide range of geopolitical pursuits (even the most contradictory ones) can be achieved. A characteristic example is the strong geopolitical alignment of Saudi Arabia, one of the most conservative countries of the Middle East and the world in general, with the U.S. the world champion of liberalism and of personal liberties.

Consequently, behind the scenes of the Syrian Crisis an undeclared war for energy supremacy and domination is taking place. From the time that certain critical safety, security and cost parameters of land energy routes became favorable (in combination with the newly discovered energy resources of Levantine Basin) Syria, mainly through its geographical position, achieved central geopolitical importance as a major hub in the energy networks of the Middle East. At the same time China and India participate in the production of oil in Syria (geo-economic benefits), Russia possesses military facilities in this country (geo- 
strategic benefits) and Israel (still) prefers the security emanating from a familiar to it regime than the highly risky benefits from a regime change in this country (security benefits).

Conclusively, the ambitious plans of Damascus in the energy sector, its long term aims and its enhanced capabilities for materialization of its plans, put it in the "cyclone eye": Syria became the center of a war for the hydrocarbons of the Middle East. The multiple military and mass media attacks (covered and uncovered) against this country are closely related to energy world competition. Furthermore, the analysis of the conflicting geopolitical interests and pursuits and of the mechanisms applied to promote them will enable us to better understand the process of "formation" of a New Order in the Region. In order to preserve the peace in the Region Turkey, Greece and Israel should work hard and methodically to achieve an understanding regarding the numerous facets of the energy issues on a medium and long term basis and the mutual benefits emanating from energy cooperation which will reduce the frictions that may arise from possible conflicting geopolitical interests.

\section{Syria's Oil}

Syria's current oil production and oil export levels are lower with comparison to 1990 ones whereas demand is constantly increasing due to Damascus policies of subsidizing oil products. According to the «Middle East Economic Survey» (MEES, 2011), Syria spent $\$ 2.5 \mathrm{Mn}$ in oil product subsidies during the first half of 2011. Note that a major part of refined oil products had to be imported. The net exports-imports balance of payments in 2006 was positive $(\$ 1.9 \mathrm{Mn})$ but since then it quickly became negative, reaching $-\$ 100$ million 2008 . Syria has announced a long term plan for the gradual abolition of these subsidies but the ongoing crisis caused a considerable delay in its realization. Syria's production of crude oil and its by-products in 2010 was $400,000 \mathrm{bbl} / \mathrm{d}$. The annual report of «The Oil and Gas Journal» (EIA, 2013), estimated that Syria's total oil reserves were 2.5 billion barrels. The known oil reserves of the country are mainly located in the eastern regions of it along Euphrates River. Other smaller fields are located in the central part of the country.

The peak of country's oil production $(582,000 \mathrm{bbl} / \mathrm{d})$ occurred in 1996 . Since then oil production rate was decreasing, going down to $387,000 \mathrm{bbl} / \mathrm{d}$ in 2010 . Note that crude oil production represents $60 \%$ of total oil production of Syria.

The biggest and ripest for exploitation oil fields of Syria are Omar Al-Furat and Jbessa, which in 2010 were estimated to have a production capacity of 100,000 and 200,000 $\mathrm{bbl} / \mathrm{d}$ respectively. The main oil production company is Al Furat Petroleum Company (AFPC), an oil conglomerate established in 1985 and consisted of Syrian Petroleum Corporation (SPC) with a 50\% share, the Syrian Shell Petroleum Development (SSPD) with a $32 \%$ share and the Himalaya Energy Syria (HES), a conglomerate of China National 
Petroleum Corporation (CNPC) and the Indian Oil \& Natural Gas Corporation (ONGC)] with a $18 \%$ share.

Syria has three oil import/export hub stations in the Mediterranean, all of them being under the management of Syrian Company for Oil Transportation (SCOT). Baniyas and Tartus are the main oil export ports of Syria followed by Latakia ${ }^{1}$. The oil terminal stations of the above ports are interconnected through a national pipeline system. In 2010 the net oil exports of Syria were estimated to be 109,000 bbl/d, approximately $7 \%$ lower than in the previous year. The oil exports of Syria are almost totally directed to European OECD countries, mainly in Germany, Italy, France and the Netherlands (EIA, 2013).

Foreign investments are vital for the improvement of oil production levels 2 . SPC directly controls half the oil production of Syria and participates with a 50\% share in investments with foreign partners. SPC is also involved in the national efforts to revert the decreasing trend in the production and exports of oil pushing forward exploration and production projects in cooperation with foreign oil companies.

Since USA sanctions prohibit the participation of American companies in Syrian projects the country initially turned its attention to Chinese, Indian and European companies. Syrian government has received, since March 2010, a number of offers in response to a tender for hydrocarbon explorations in eight oil land fields. Total and Petro-Canada were the first foreign firms to be granted exploration permissions in 2011. Syria possesses also sea oil fields which are also open for exploration. The Syrian Ministry for Oil and Mineral Resources announced a tender for three coastal natural gas fields with 5 October 2011 being the terminal date for offer submissions. Furthermore, the above ministry in cooperation with the General Establishment of Geology and Mineral Resources (GEGMR) announced a new tender for oil exploration and production in the slate oil field of al-Khanasir, 60 miles southeast of Aleppo. The tender area consists of 14 sectors with total oil reserves estimated to be 39 billion tons. The deadline for the submission of offers was 30 November 2011.

Therefore as initial observation the interests of American companies and the U.S. could not be promoted in Syria compared with those of European, Russian and Chinese.

1 We noted the Russian naval facility in Tartus, a military installation of the Russian Navy located in the port of the city of Tartus.

2 This sector (of foreign investments) received an almost lethal blow during the '80s as a result of an embargo imposed by the West. 


\section{Syria's Pipelines}

U.S. announced their decision to construct a huge pipeline network as early as February 1944. This network, having a total length equal to $2,000 \mathrm{~km}$, aimed to connect Persian Gulf oil fields with Mediterranean ports. At the same time U.S. announced their plans to upgrade and extend the refineries of Bahrain, Alexandria and Haifa. The above plans were sound from strategic point of view because they would allow for U.S. to avoid sea routes which were too dangerous as a result of the war, not excluding of course the existence of other geo-strategic motives in the back of their minds. On the other hand, London foresaw behind these plans an aim of the United States to downgrade the role of Suez Canal (being under its control) and a long term plan to "americanize" the oil transport system in the Middle East. As a result the British proceeded with a protest to the Saudi King to stop the plans of Washington. Despite this protest the U.S. proceeded with their plans. The project was undertaken by the American oil company Aramco which constructed Tapline (TransArabian Pipeline) with a capacity of 500,000 bbl/d which connected the al-Zahran oilfields with the port of Sidon in Lebanon. Tapline became operational in 1950. The negotiations regarding Tapline played a decisive role in the relations of U.S. with Syria and Britain.

A pipeline partially competitive to Tapline was Middle East Pipeline (MEPL), a pipeline designed by a conglomerate of an Iranian-British oil company (with a majority share) and American firms. MEPL would connect Iranian oil fields with Syrian ports passing through Iraq ${ }^{3}$.

After the Israeli-Arab War of 1967, the Tapline section crossing Golan Heights was set under Israeli control with the Israelis permitting the unobstructed function of it. As a result of continuous disputes between Saudi Arabia, Syria and Lebanon regarding the oil transport fees, the part of it beyond Jordan ceased to be functional in 1976. The rest of the pipeline, between Saudi Arabia and Jordan, continued to transport small quantities of oil until 1990 when Saudi Arabia interrupted the flow of oil as a result of the 1st Gulf War. Today the pipeline is unsuitable for oil transportation. Nevertheless, the Tapline remains a possible (and promising) path for the export of oil from the Persian Gulf to the West. A recent economic study has shown that the cost of transportation of oil through Tapline (with the port of Haifa as its export terminal) to Europe would be $40 \%$ lower than the corresponding sea (tanker) cost through the Suez Canal. In the beginning of 2005, the restoration of Tapline, at an estimated cost of $\$ 300$ million, was one of the strategic options under consideration by the government of Jordan in its efforts to cover its oil needs.

During the 1950s a second pipeline system was constructed to transport oil from Kirkuk, in northern Iraq, to the port of Baniyas in Syria and to the port of Tripoli in Lebanon.

3 This pipeline was never constructed. 
The major part of this pipeline system, having a length of $800 \mathrm{~km}$, was destroyed by the American air force in 2003 during the Iraqi War ${ }^{4}$. Recently, the governments of Iraq and Syria agreed to restore this pipeline system and to construct also a new one. Actually, in June 2011 Syria and Iraq signed a memorandum agreement for the restoration of the existing pipeline system (with a capacity of $800,000 \mathrm{bbl} / \mathrm{d}$ ) and the construction of two new pipelines for the transportation of heavy-graded oil (with a capacity of $1.5 \mathrm{million}$ bbl/d) and of lightgraded oil (with a capacity of 1.25 million $\mathrm{bbl} / \mathrm{d}$ ).

Besides the above two interstate pipeline systems, Syria has developed a domestic pipeline network for the transportation of crude oil and the products managed by SCOT. This network includes the Tel Adas - Tartus pipeline (345 miles and 250,000 bbl/d) which connects the Tel Adas oil fields with the port of Tartus with a sub-connection to Homs refinery and also a system of transport lines for the flow of Homs refinery oil products to the main urban centers of Syria.

Thus, from the beginning the geographical location of Syria and the Syrian ports were important for the handling of oil in the eastern Mediterranean.

\section{Syria's Oil Refineries}

According to the annual report of «The Oil and Gas Journal» (EIA, 2013) the total capacity of Syrian refineries was approximately $240,000 \mathrm{bbl} / \mathrm{d}$. The two state refineries of Syria are located in Baniyas and Homs, having refinement capacities 133,000 bbl/d and $107,000 \mathrm{bbl} / \mathrm{d}$ respectively. Syria faces shortages with internal combustion fuel and diesel and a considerable increase of domestic refinement capacity is needed to meet demand. On the other hand, foreign oil companies hesitate to provide necessary investment capitals for the construction of new refineries in Syria without an adequate support from its government. In December 2010, Venezuela signed a memorandum of understanding for the construction of a refinery (with 140,000 bbl/d capacity) in Froklos, a project which had been suspended after an agreement for its construction in March 2008, (Syrian Oil \& Gas News, 2009). Also, Chinese officials have discussions with the Syrian government on the construction of a refinery (with capacity 70,000 bbl/d) near Deir al-Zor oil fields, which is a considerably delayed project the realization of which should had been started in 2008 .

4 Twenty three years before the destruction of this pipeline, at the beginning of the Iraqi-Iranian war (19801988), the president of Syria Hafez al Assad ordered the suspension of oil flow in this pipeline. Note Hafez al Assad was the only Arab leader who supported Iran in the war against Saddam Hussein. 


\section{Syria's Natural Gas}

According to the annual report of «The Oil and Gas Journal» (EIA, 2013), the proved reserves of Syria's natural gas are estimated at the level of 8.5 trillion cubic feet (TCF). Sixty per cent of the above reserves are of the form «Associated Petroleum Gas» (APG). In 2009, approximately one quarter of Syria's gross production of natural gas was used to upgrade oil pumping operations. The major part of gas production is directed to electric energy production and household users. Currently, the burning systems of all electricity production units of Syria are undergoing a modification process to burn natural gas instead of petrol. As a result of the above changes the domestic demand for natural gas is expected to increase by $100 \%$ until $2020^{5}$. Despite the fact that the extraction of Syria's natural gas is expected to follow an increasing trend, still it will remain inadequate to cover expected demand. As a result Damascus is planning to import increased quantities of natural gas. In 2009, Syria produced 219 BCF dry natural gas, consuming $251 \mathrm{BCF}$ and exporting $32 \mathrm{BCF}$. Gas production reached a peak of $252 \mathrm{BCF}$ in 2004 , but it is expected to be increased in the near future since some of the (planned) land gas installations have become operational. On top of that, following a tender announced in March 2010 regarding 8 land gas fields, Total and Petro-Canada are expected to be the first companies to be granted exploration permits, (Syrian Oil \& Gas News, 2010). Syria has also announced a tender for gas exploration in coastal sectors in eastern Mediterranean. It has been published (Osama Habib, The Daily Star, 2012), that the discovery of vast reserves of natural gas in coastal areas of Israel led to the revival of the interest for gas exploration in neighbouring coastal areas of Lebanon, Cyprus and Syria. Following the discouraging reactions to a tender announced by Syria in 2007, the Syrian Ministry of Petroleum and Mineral Resources and the Syrian General Petroleum Corporation (GPC) selected three coastal lots to be included in a new tender with 5 October 2011 being a terminal date for the submission of offers. Note at this point that Lebanon decided to announce a tender for natural gas exploration in coastal areas in the first quarter of 2012 but due to problems in the organization of state infrastructures supporting the project the announcement of the tender was delayed for the end of the year (Karbuz, 2012).

\section{Syria's Natural Gas Imports and Pipelines}

Syria is planning to become soon a natural gas exporter. In the context of this plan Syria has completed the construction of a gas pipeline to Lebanon since 2003. Nevertheless, until 2009 the natural gas quantity available for delivery was insufficient and as a result (from mid-2008) Syria became an importer of gas. In 2008 Syria imported 5 BCF from

5 Note that Syria is characterized by an extremely high population growth rate: in 1962 its population was only 4 million and now has reached 23 million. 
Egypt through the Arab Gas Pipeline (AGP). The long term objective of Syria is to become a hub country in the Middle East energy pipeline networks interconnecting Egypt, Iraq, Iran and Azerbaijan. As a hub Syria will achieve multiple benefits: increased income from transfer fees and also increased quantities of available gas. In particular, through AGP Egyptian natural gas is transported to Jordan and Syria and through a special pipeline to Israel. Although Egypt cannot supply directly Lebanon with gas, nevertheless this takes place indirectly through an exchange agreement in the context of which Egypt supplies Syria with gas through AGP and Syria transfer analogous amount of gas to Lebanon through the Syria-Lebanon export pipeline. The above gas supply process to Lebanon has exhibited many problems especially after February 2011.

In 2009 Syria and Turkey signed a memorandum agreement according to which Ankara would construct a 56 miles pipeline inside its territories up to the borders with Syria and this pipeline would be connected with an extension of AGP pipeline (from Aleppo to Kilis) under construction by Syria. The above project was to be completed within 2012. According to this agreement Turkey would supply Syria with 17-35 BFC gas for 5 years. In June 2010 Syria and Azerbaijan signed a protocol according to which the latter would supply Syria with natural gas through Turkey starting from 2012. The above supply of Syria with gas (initially with 35 BFC annually up to 70 BFC until 2015) depended upon the completion of AGP pipeline extension needed to implement the connection of pipeline networks of Syria and Turkey.

As a next step to its plans to become an energy hub in the Middle East, Syria signed, in July 2011, an agreement with Iran and Iraq for the construction of Islamic Gas Pipeline, (IGP) aiming to the supply of European markets with natural gas, (Syrian Oil \& Gas News, 2012). It regards a 3.100 miles pipeline capable of transporting $1.4 \mathrm{TCF} / \mathrm{y}$ of natural gas from the huge South Pars deposits to the Mediterranean coast (and Europe) through Iraq, Syria and Lebanon. IGP, which does not pass through Turkey, has a capacity $30 \%$ larger than Nabucco pipeline which is planned to connect Erzurum in Turkey with Austria. The construction of this pipeline is expected to last for 3-5 years and its cost is estimated to reach 10 bil \$. The U.S. dismissed reports that construction had begun on the pipeline, saying that this had been claimed repeatedly and that "plans by Iran to build a natural gas pipeline through Iraq to Syria may run into problems with economic sanctions"6. Note that this agreement, which reduces the importance of Turkey as an energy networks hub in the Middle East, coincides with the change in Ankara's policy towards Damascus.

6 UPI, 20 November 2012, U.S. brushes off Iran-Iraq-Syria gas line, <http://www.upi.com/Business_News/Energy-Resources/2012/11/20/US-brushes-off-Iran-Iraq-Syria-gasline/UPI-36621353414380/>, 10.09.2013. 
Finally one can stress the fact that IGP is compatible with the American policies of drastically reducing E.U. dependence on Russian natural gas.

All these developments and the plans of Damascus significantly increased the importance of Syria in the energy map of the Eastern Mediterranean and caused the U.S. response (Dinucci, 2013; Nafeez, 2013; Butter 2014; Maj. Taylor, 2014). We must not forget the dependency of U.S. on Middle East oil and that the great power rivalries for energy is continuous and strong (Kubicek, 2013).

\section{Conclusions}

It has been argued (Karkazis, Vidakis, Baltos, 2013: 104) that when Israel initiated in 2009 a huge program of oil and gas explorations it became clear that Eastern Mediterranean had entered in a new period of «energy geopolitics». Syria possesses a significant part of the mineral wealth of the area which attracts the interest of international oil companies. In this context, the "Four Seas" policies adopted by president Assad in the beginning of 2011 (only a few months before the eruption of the crisis) was aiming to transform Syria to an oil and gas transport hub connecting the energy sources of Black Sea, Caspian Sea and Persian Gulf with Mediterranean ports of Syria and Lebanon. IGP was another major investment plan with its completion expected for 2016. IGP presented an alternative option for the transportation of Iranian natural gas to European markets, an option not at all desirable by the Arab countries of the Gulf and especially Saudi Arabia.

Besides that, the planned re-operation of the oil pipeline connecting Kirkuk with the port of Baniyas in Syria (with relevant construction works to be undertaken by local public companies and not by international oil companies) constitutes a significant parameter in the «geopolitics of energy». To complete the geo-strategic puzzle note that China participates directly in the production of oil in Syria and Israel seems to prefer the stability and security of a regime for which it has attained a long time geopolitical familiarization than the risks emanating from the highly stochastic nature of the rebel forces.

The political turmoil in Syria started in March 2011. Following Assad's violent and bloody repression of social uprisings, first U.S. and then E.U. imposed sanctions on Damascus. New rounds of sanctions, directed on the energy sector of Syria, were imposed in August 2011. As a result of the above sanctions the American oil companies were prohibited from taking part in projects regarding the exploration and exploitation of the energy resources of Syria and to take advantage of its position as an emerging energy transport hub in the region. U.S. worked hard in the diplomatic sphere to prevent competitors from entering the Syrian vacuum, persuading E.U. and pressing Britain to the limits to join sanctions against the Syrian regime. France, although it has historical interests and exercises a strong influence in Syria and Lebanon, appears not willing to oppose Washington plans. 
Turkey, after a short period of wavering, took a clear and decisive position against Assad's regime.

Conclusively, one of the contributing factors to the Syrian crisis seems to be an escalating 'geo-energy war': as soon as the comparative differential geopolitical significance of energy paths and the various energy resources of the Levant Basin were clearly recognized, Syria acquired an enhanced geostrategic importance, (Karkazis, Vidakis, Baltos, 2010: 108-111). Furthermore, the upgrading of Syria as an energy hub would considerably reduce the benefits enjoyed by Washington from the control of the Persian Gulf and at the same time would result in the reduction of the dependence of E.U. on Russian energy resources and on energy paths controlled by the U.S. The above may also explain, to some degree, the growing geopolitical understanding developed recently between U.S. and Russia on Middle East issues. If we cross-examine the above with the enormous interests of American oil companies in the Region (and their influence on governmental politics) and the long term Washington policies to isolate Iran (and also Syria in its capacity as an ally of Tehran) then we can more clearly recognize the option of rupture with the Syrian regime. Finally, as we may conclude from the following remarks Turkish geostrategic interests could be also hurt.

A fall of Assad's regime would open the door to the restoration of only the Kirkuk-Baniyas pipeline (at least initially) the design of which took place in 1930 to allow for the transportation of Iraqi oil to Mediterranean ports. This restoration will be undertaken by western firms and this will lead to the entrance in Syria of western multinational oil companies (under the American auspices) and the subsequent uncontrolled exploitation of its energy resources. We stress at this point a norm (prerequisite) in the geopolitics of energy: before the great powers proceed with strategic investments in the area of hydrocarbons they try their best to secure first the long-term stability and friendliness of the geopolitical environment.

\section{References}

Butter, David (2014), Carnegie Endowment. Fueling Conflict: Syria's War for Oil and Gas, (2 April 2014), < http://carnegieendowment.org/syriaincrisis/?fa=55195>, 30.06.2014.

Dinucci, Manlio (2013), Global Research. Oil and Pipeline Geopolitics: The US-NATO Race for Syria's Black Gold, (7 April 2013), <http://www.globalresearch.ca/oil-and-pipelinegeopolitics-the-us-nato-race-for-syrias-black-gold/5330216>, 10.09.2013.

Habib, Osama (2012), “Lebanon's offshore gas likely exceeds Cyprus, Syria”, The Daily Star, (7 September 2012), <http://www.dailystar.com.lb/Business/Lebanon/2012/Sep-07/187039lebanons-offshore-gas-likely-exceeds-cyprus-syria.ashx\#axzz2BAuAnqXB>, 10.09.2013. 
Karbuz, Sohbet (2012), "Eastern Mediterranean Gas: Source for Cooperation or Fuel for Conflict?", Journal of Turkish Weekly (JTW), (25 June 2012), <http://www.turkishweekly.net/oped/2985/-eastern-mediterranean-gas-source-for-cooperation-or-fuel-for-conflict.html>, 10.09.2013.

Karkazis, J \& I. Vidakis \& G. Baltos (2013), “The Energy Wealth of Syria”, Foreign Affairs, The Hellenic Edition, 20, 104-118.

Karkazis, J. \& I. Vidakis \& G. Baltos (2013), “Geo-energy - a new reading of the world”, Greek Defence \& Technology, 1 (3), 104-113.

Kubicek, Paul (2013), "Energy politics and geopolitical competition in the Caspian Basin", Journal of Eurasian Studies, 4 (2), 171-180.

Maj. Taylor Rob, (2014), "Pipeline politics in Syria”, Armed Forces Journal, (21 March 2014), <http://www.armedforcesjournal.com/pipeline-politics-in-syria/>, 30.06.2014.

Middle East Economic Survey (2011), Syria Spent \$2.5Mn Subsidizing Petroleum Products in 1H 2011, (31 July 2011). <http://www.mees.com/en/articles/2178>, 10.09.2013.

Nafeez, Ahmed (2013), "Syria intervention plan fueled by oil interests, not chemical weapon concern", The guardian, (30 August 2013), <http://www.theguardian.com/environment/earth-insight/2013/aug/30/syria-chemicalattack-war-intervention-oil-gas-energy-pipelines>, 10.09.2013.

Syrian Oil \& Gas News (2009), Chaves calls to accelerate implementing of joint Oil Refinery Project between Syria and Venezuela, (6 September 2009), <http://www.syriaoil.com/en/?p=526\#more-526>, 10.09.2013.

Syrian Oil \& Gas News (2010), PetroCanada is preparing to start drilling exploratory well Manda 1 in Block 2 in Hasakah, (5 May 2010), <http://www.syria-oil.com/en/?p=793\#more793>, 10.09.2013.

Syrian Oil \& Gas News (2012), Iran's gas pipeline to Iraq has seen a physical progress, (2 February 2012), <http://www.syria-oil.com/en/?p=2234\#more-2234>, 10.09.2013.

U.S. Energy Information Administration (EIA) (2013), Syria Analysis, (20 February 2013), <http://www.eia.gov/countries/cab.cfm?fips=SY>, 10.09.2013. 